\title{
FIBROCYSTIC DISEASE OF THE PANCREAS PRESENTING WITH ACUTE SALT DEPLETION
}

\author{
BY \\ JOHN RENDLE-SHORT \\ From the Department of Child Health, the University, Sheffield
}

(RECEIVED FOR PUBLICATION AUGUST 14, 1955)

During the hot summer of 1948,10 patients were admitted to the Babies' Jospital in New York with heat prostration. No fewer than five of these children were cases of fibrocystic disease of the pancreas. Two further cases were discovered in subsequent summers. Reporting this interesting observation, Kessler and Andersen (1951) recorded that this special susceptibility to heat occurred in children who from the point of view of the fibrocystic disease seemed to be doing well; indeed, one child was thought to be normal and it was only in later investigations that he was found to have any underlying disease. Clinically the cases presented with vomiting, pyrexia and dehydration. Two children perspired freely, and in the two cases in which the observation was made low plasma chlorides were found on admission, namely, 59 and $81 \mathrm{mEq}$./litre (335 and $526 \mathrm{mg}$. per $100 \mathrm{ml}$.).

Stimulated by this work, Di Sant'Agnese, Darling, Perera and Shea (1953) measured the quantity and electrolyte composition of the sweat in cases of fibrocystic disease. No difference in the volume of sweat was noted between the children with the disease and controls and great individual variations were observed in both groups. The electrolyte content of the sweat, however, was significantly higher in children with fibrocystic disease (Table 1).

Di Sant'Agnese and his colleagues gave details of a further six cases of heat prostration in children with fibrocystic disease occurring in the summer of

TABLE 1

ELECTROLYTE CONTENT OF SWEAT IN 43 PATIENTS WITH FIBROCYSTIC DISEASE AND 50 CONTROLS*

\begin{tabular}{|c|c|c|c|c|c|}
\hline \multirow{3}{*}{ r } & \multicolumn{5}{|c|}{ Electrolyte Content of Sweat (mEq. per litre) } \\
\hline & \multicolumn{2}{|c|}{ Chloride } & \multicolumn{2}{|c|}{ Sodium } & \multirow{2}{*}{$\begin{array}{c}\begin{array}{c}\text { Potas- } \\
\text { sium }\end{array} \\
\text { Mean }\end{array}$} \\
\hline & Range & Mean & Range & Mean & \\
\hline $\begin{array}{l}\text { Fibrocystic disease } \\
\text { Controls } \ldots\end{array}$ & $\begin{array}{r}60-160 \\
4-80\end{array}$ & $\begin{array}{r}106 \\
32\end{array}$ & $\begin{array}{l}80-190 \\
10-120\end{array}$ & $\begin{array}{r}133 \\
59\end{array}$ & $\begin{array}{l}18 \\
12\end{array}$ \\
\hline
\end{tabular}

* Figures taken from Di Sant'Agnese et al. (1953).
1952. It is notable that the ages of these children ranged from 3 to 13 years; four of them had little respiratory involvement and the other two had only mild pulmonary disease.

No case of heat prostration associated with fibrocystic disease of the pancreas has yet been described in Great Britain, presumably for climatic reasons. Nor have any cases been recorded in this country or abroad of the disease presenting with salt depletion in the absence of excessive heat. The following case record is therefore of interest.

\section{Case Record}

Ken , th weighed $6 \mathrm{lb} .12 \mathrm{oz}$. at birth. His father suffers from diabetes mellitus, but his mother and three siblings are healthy. Kenneth was successfully breast fed and appeared to be perfectly well until three weeks before his admission to hospital in October, 1954, at the age of 3 months. He then started to cough and his respirations became laboured and grunting, but at that time no abnormal physical signs could be found. During the next few days he had bouts of crying, between which he was quite cheerful and smiling. He sweated considerably and his mother subsequently remarked that he 'tasted salt'. Although there was a fire in his room his parents state that he was not covered by an excessive number of bed-clothes. His motions were small and green and his urine became scanty: two days before admission he was dry for 21 hours. Throughout the illness he continued to feed well at the breast and only vomited on one occasion after he had been given oral penicillin. He was seen several times by his family doctor and given intramuscular penicillin, but no abnormal physical signs could be found. The night before admission the child suddenly went limp and blue. His breathing appeared to stop and his eyes turned upwards. After about 10 minutes he rallied and sucked at the breast. He was then sent into hospital. On admission he was found to be an ill, grossly dehydrated baby with pink lips. His respiration rate was 38 per minute and nothing abnormal was found in the chest, heart, abdomen, ears or urine. A chest radiograph was normal. At first sight the most probable diagnosis seemed to be gastroenteritis, but he was a breast-fed baby and a stool passed 
while he was being examined was small, emerald green and of normal consistency. Diabetes mellitus was also considered in view of the family history, but the normal character of respirations made this improbable; there had been no polyuria and his blood sugar was $135 \mathrm{mg} . \%$.

The possibility of an Addisonian crisis and adrenogenital syndrome was considered, although the genitalia were normal and the family history was negative. Biochemical investigations were performed with the following results:

Plasma chloride (as $\mathrm{NaCl}), 365 \mathrm{mg} . / 100 \mathrm{ml}$. $(62 \cdot 0$ $\mathrm{mEq}$./litre); plasma bicarbonate, 80 vol./100 ml. (36.0 $\mathrm{mEq}$./litre); plasma sodium, $280 \mathrm{mg} . / 100 \mathrm{ml}$. (122 mEq./ litre); plasma potassium, $16.2 \mathrm{mg} . / 100 \mathrm{ml}$. (4.6 mEq.) litre).

The diagnosis of an Addisonian crisis was finally abandoned when, after a period of anuria, a specimen of urine was obtained and was found to contain no chloride.

Symptomatic treatment for the dehydration and salt loss was instituted, the child being given normal saline intravenously and desoxycorticosterone acetate (D.O.C.A.) and cortisone intramuscularly. Each specimen of urine was tested for chlorides and daily plasma chlorides estimations were performed. These levels both rose satisfactorily and the plasma bicarbonate fell to normal. Four days after the start of therapy the biochemical changes had been somewhat overcorrected; the urinary chlorides were now $808 \mathrm{mg}$. $/ 100 \mathrm{ml}$. (137 $\mathrm{mEq}$./litre) and the plasma potassium had risen to $26.0 \mathrm{mg}$. $/ 100 \mathrm{ml}$. (6.6 mEq./litre). The 17-ketosteroids were $0.2 \mathrm{mg}$. per day and the 17-ketogenic-steroids $2.5 \mathrm{mg}$. per day, figures which are within normal limits.

When the child's biochemical upset had eventually been corrected his general condition was excellent. He was discharged home still breast feeding, but requiring a small complement.

At that time no cause for the dehydration was discovered. It was assumed that he had had an illness during which he sweated excessively and lost a large quantity of water and sodium chloride. The electrolyte content of his mother's breast milk was measured while she was in hospital with the following results:

Chloride, $74 \mathrm{mg} . / 100 \mathrm{ml}$. (12.6 mEq./litre); sodium, $13 \mathrm{mg} . / 100 \mathrm{ml}$. (5.9 mEq./litre); potassium, $53 \mathrm{mg} . /$ $100 \mathrm{ml}$. (13.6 mEq./litre).

After discharge the child was not seen at the hospital for nine months as the family live some distance away, but the family doctor, Dr. Mainman, kindly informed us of his condition during this time. He reported that the only complaint by his mother was of offensive smelling stools. This symptom persisted and four months later the child developed a respiratory infection which proved very resistant to treatment. A radiograph of the chest then showed generalized hyperaemia most evident at the lung bases and consistent with a recent infection. During this time he developed a right inguinal hernia for which he was again referred to hospital.

The history of an intractable respiratory infection and foul-smelling stools coupled with the previous episode of acute dehydration immediately suggested the diagnosis of fibrocystic disease of the pancreas and efforts were made to confirm this.

Clinically the child looked well; his weight at 1 year was $22 \mathrm{lb}$. There were no abnormal physical signs apart from a reducible right inguinal hernia. His stools were very foul and his mother stated that fat oozed from the anus, but we were unable to confirm this.

Specimens of duodenal juice and stool both showed tryptic activity up to a dilution of 1 in 5 only. No iodine was detectable in the urine up to 24 hours after ingestion of $5 \mathrm{ml}$. iodized poppy seed oil B.P. (Silverman and Shirkey, 1955). A fat balance on a 37 g. per day fat intake showed that the child absorbed $84 \%$ of fat. A radiograph of the chest showed patchy collapse and emphysema. Analysis of saliva and sweat (obtained by the method of Shwachman, Leubner and Catzel, 1955) gave the following results:

$$
\begin{aligned}
& \text { Saliva \{Sodium } \quad \cdots \quad 48 \mathrm{mEq} . \text { per litre }(110 \mathrm{mg} \cdot / 100 \mathrm{ml} \text {. } \\
& \text { Saliva } \begin{array}{llr}
\text { Chloride } & & 45 \mathrm{mEq} \text {. per litre }(263 \mathrm{mg} . / 100 \mathrm{ml} .)
\end{array} \\
& \text { Sweat }\left\{\begin{array}{lll}
\text { Sodium } & \ldots & 122 \mathrm{mEq} . \\
\text { Chloride } & \ldots & 106 \mathrm{mEq} \text {. per litre }(263 \mathrm{mg} . / 100 \mathrm{ml} .)
\end{array}\right.
\end{aligned}
$$

These results are consistent with those obtained in fibrocystic disease of the pancreas by Di Sant'Agnese et al. (1953).

\section{Discussion}

During Kenneth's first hospital admission his stools were reported as normal apart from a single occasion just before his discharge. At this time he was receiving breast milk with a small complement of National dried milk. His mother weaned him off the breast soon after he returned home, the stools then becoming very offensive. It is possible that the innocuous nature of the stools in hospital may have been due to the fact that he was breast fed, the alimentary involvement only becoming manifest when he was weaned. On the other hand, as has been shown by Di Sant'Agnese (1955), pancreatic involvement is not essential for the diagnosis of fibrocystic disease, and perhaps the child's pancreas was not severely damaged by the age of 3 months.

The main interest in this case lies in the fact that the patient developed acute salt depletion from excessive sweating due, not to heat, but to some unknown illness. This was probably a respiratory infection, but it could have been paroxysmal tachycardia or some other condition. Acute salt depletion is therefore a danger to which children with fibrocystic disease are exposed whenever they have an illness in which they perspire freely. Extra salt should be given at these times. Conversely, it is obvious that any child with heat prostration or unaccountable dehydration should be investigated for possible underlying fibrocystic disease of the pancreas. 


\section{Summary}

A case of fibrocystic disease presenting with dehydration and salt depletion is recorded.

The water and salt loss was due to excessive sweating occasioned not by heat, but by an illness, probably a respiratory infection.

My thanks are due to Dr. A. Livingstone and Dr. E. R. Mainman, who referred this child to us and who kept us informed of his progress, to Miss E. Finch who performed the biochemical investigations and to Professor R. S. Illingworth for his helpful criticism.

\section{REFERENCES}

Di Sant'Agnese, P. A. (1955). Pediatrics, 15, 683 Darling, R. C., Perera, G. A. and Shea, E. (1953). Ibid. 12, 549

Kessler, W. R and Andersen, D. H. (1951), Ibid., 8, 648.

Shwachman, H., Leubner, H. and Catzel, P. (1955). Advances in Pediatrics, Vol. VII, p. 249.

Silverman, F. N. and Shirkey, H. C. (1955). Pediatrics, 15, 143. 